\title{
Art Lawyers' Due Diligence Obligations: A Difficult Equilibrium between Law and Ethics
}

\author{
Sandrine Giroud*
}

\section{Charles Boudry ${ }^{\dagger}$}

\begin{abstract}
This article examines the duties of diligence of lawyers when handling art-related matters. Due diligence is paramount to any activity in the art market and a key element in ascertaining ownership, authenticity or provenance. In particular, it is a benchmark to help determine the existence of possible criminal activities, including money laundering, terrorism financing or document forgery, to which the art market is regularly exposed. The question arises as to the obligations incumbent to art lawyers who are privileged witnesses of the functioning of the art market. Such obligations include in particular the duty to enquire on the particularities of a transaction, the duty to terminate a mandate or the duty to report any suspicious transaction under threat of civil or criminal sanctions. A survey has shown that art law specialists would welcome more guidance in the form of tailored regulations or professional guidelines.
\end{abstract}

\section{INTRODUCTION}

Due diligence, a relative and multifaceted concept, is of paramount importance for any activity in the art market.

Yet, despite progress in the legislative implementation of this concept and increased awareness of its legal consequences, instances of illegal and unethical conduct in the art market continue to make the headlines, raising questions as to the diligence of the actors involved in the art market. The Wolfgang Beltracchi or

${ }^{*}$ LALIVE, Geneva. Email: sgiroud@lalive.ch

$\dagger$ LALIVE, Geneva. Email: cboudry@lalive.ch 
Pei-Shen Qian forgery scandals and the recent archaeological looting in Iraq and Syria to support terrorist activities are but a few of the many recent examples of an all too common phenomenon in a market worth billions of dollars. ${ }^{1}$ As the world art market is becoming ever more financially important, art is being increasingly commoditized. In such circumstances, the need for transparency is greater than ever and close attention needs to be paid to defining the scope of the few applicable rules, particularly those relating to the due diligence obligations that must be carried out by those operating in the art market.

Art lawyers, as privileged witnesses of the functioning of the art market, are key to enforcing due diligence obligations. They must not only draw the attention of their clients to the risks and due diligence obligations associated with art transactions, but they must also themselves abide by high standards concerning their professional due diligence obligations. The absence of diligence in art transactions can have dire consequences such as the obligation to pay compensation, invalidation of contracts and even criminal charges in cases of money laundering, financing of terrorist activities, document forgery, or concealment. Legal practice is of course itself extensively regulated. However, while the body of laws, as well as professional standards and ethical rules to which lawyers are subjected set out the general duties owed to clients, they offer no specific guidance as to what art lawyers should do when faced with suspicious art transactions - an issue that scholars seldom, if ever, touch upon.

This article attempts to examine the various aspects of a lawyer's role and duties of diligence in the art market and to assess whether specific legally binding rules, professional standards, or ethical guidelines should be implemented. After examining due diligence obligations as applicable in the art world (section I), this article will review the role and duties of art lawyers when handling art-related matters (section II). It will do so by employing a comparative law approach that focuses on the applicable laws, rules and standards of different jurisdictions such as France, Germany, Italy, the State of New York, Switzerland, the United Kingdom and the Netherlands. Finally, based on empirical data, this article will consider whether and to what extent art lawyers want to and should play a role in ensuring that the ethical and legal rules in the art market are respected through the implementation of new regulations or guidelines on their due diligence obligations (section III).

\section{DUE DILIGENCE OBLIGATIONS IN THE ART WORLD}

\section{Diligence in the Art Market}

At the heart of the discussion about due diligence obligations in the art world are recurring issues such as illicit trafficking, fakes, forgeries, looted art, money laundering, the trading of objects from unknown sources, and the restitution of cultural goods to the country of origin.

The United Nations Educational Scientific and Cultural Organisation (UNESCO) estimates that, together with the trafficking in drugs and in arms, "the black market 
of antiquities and culture constitutes one of the most persistent illegal trades in the world" and from illegal excavation to final sale, "the value of the most beautiful masterpieces increases 100 fold, a greater growth than that of drugs." 2 According to scholars, $80 \%$ of Etruscan and Roman antiquities on the market today come from illegal sources. ${ }^{3}$

The market of antiquities, for example, is a highly-sophisticated and lucrative business involving a significant number of actors. It is not unusual for one transaction to use several intermediaries, without disclosing the names of the buyer and seller. Given the amounts at stake, criminal organisations are frequently involved, raising the possibility of money laundering and the financing of terrorism. ${ }^{4}$ This has recently been illustrated by the emergence of the so-called Islamic State (IS), which has made millions from the looting and trafficking of Iraqi and Syrian antiquities and is partially "financing its carnage with the wealth of past civilizations."

Over the years, such concerns have triggered the enactment of more stringent regulations and the continuing development of the concept of due diligence applicable to the various stakeholders in the art market.

\section{The Legal and Ethical Framework of Due Diligence in Art-related Matters}

Largely self-regulated, the art market is characterized by a complex interplay of legal rules and ethical rules; an overlap which also exists within the concept of due diligence. Although the concept of due diligence is regularly referred to in statutes, implementing it in a particular context is often left to one's discretion.

\section{Due Diligence: A Legal Concept}

The concept of due diligence arises in different areas of the law related to art, as determined and shaped by domestic and international instruments, as well as case law.

Different legal instruments refer, directly or indirectly, to the concept of due diligence. In general, the emphasis is placed primarily on the notion of good faith, as is the case, for example, in Article 7(b)(ii) of the 1970 UNESCO Convention on the Means of Prohibiting and Preventing the Illicit Import, Export and Transfer of Ownership of Cultural Property (1970 UNESCO Convention). Diligence obligations can also be found in Article 4(1) of the 1995 UNIDROIT Convention on Stolen or Illegally Exported Cultural Objects (1995 UNIDROIT Convention), which imposes on the owner of an object the duty to establish that he or she has acted with due diligence-a reversal of the usual burden of proof regarding good faith. Article 4(4) of the 1995 UNIDROIT Convention also sets out the aspects of a transaction subject to the duty of diligence, namely the circumstances of the acquisition, the experience of the parties and the price paid. It also sets out some specific obligations, including the obligation to consult a register of stolen cultural objects and to review any other relevant and accessible information. The recent European 
Directive 2014/60/EU of 15 May 2014 on the Return of Cultural Objects Unlawfully Removed from the Territory of a Member State contains a provision similar to that of the 1995 UNIDROIT Convention.

In domestic law, there has been little codification of the concept of due diligence-the applicable national legislation referring primarily to the principle of good faith. ${ }^{6}$ In Switzerland, professionals active in the art trade and auction business must comply with various duties of diligence when engaging in transactions concerning cultural property. These include verifying the seller's identity, keeping and recording the transaction documents and granting access to the business premises to the relevant authorities. ${ }^{7}$ In England and Wales, the notion of due diligence in the acquisition of cultural goods is not regulated by any specific law or regulation, but appears in the 2007 Money Laundering Regulations. ${ }^{8}$ The Netherlands has, in contrast, made a specific effort to codify the concept of due diligence. The Dutch national law implementing the 1970 UNESCO Convention sets out in detail the circumstances of the acquisition to be taken into account and the steps that must be taken by the buyer, commercial dealer, and auctioneer in order to establish good faith. ${ }^{9}$

More generally, in a civil context - as understood under continental law and in contrast to administrative and criminal laws-due diligence is a key element for ascertaining ownership, authenticity, or provenance of an artwork or a cultural object. The concept is directly connected to the principle of good faith; the requirement to act diligently by verifying authenticity or origin may be a criterion or an indicator in establishing good faith. In most civil law countries, the acquisition of a good faith purchaser is protected (usually after a certain period of time), even if the object turns out to have been stolen. ${ }^{10}$ In common law systems, title in stolen property cannot generally be transferred by virtue of the nemo dat quod non habet principle (literally meaning "no one gives what he doesn't have"). ${ }^{11}$ However, due diligence and good faith will play a role in determining the compensation due to a purchaser who is forced to return stolen property to its rightful owner. ${ }^{12}$ Due diligence is also a benchmark to determine the existence of possible criminal activities, including money laundering, terrorism financing, document forgery, or concealment. Unfortunately, these activities are not unusual in the art world due to factors such as the existence of valuable cultural objects in areas dominated by armed conflicts, the relative ease with which high-value objects can be transported, customs officers' lack of specific training and enforcement authorities' lack of formal or material powers. The increasing commoditization of art for investment purposes but also as a "refuge value" implies additional due diligence obligations, as set in particular by financial and banking regulations among others, to ensure tax compliance (e.g. the 2012 Revised Recommendations of the Financial Action Task Force (FATF) expanded the scope of money laundering predicate offenses to include tax offenses)..$^{13}$

The concept of due diligence is further shaped by case law. The recent $A C A$ Galleries, Inc. $v$ Kinney decision before the New York Southern District Court 
constitutes an example of a court inquiring into the relevance and scope of due diligence obligations. ${ }^{14}$ In that case, an art gallery sued an art dealer for selling a forged Milton Avery painting. The New York Southern District Court dismissed the fraud claims, holding that ACA could not "establish justifiable reliance [on the dealer's misrepresentations] because it had the opportunity to fully investigate the authenticity of the painting but failed to do so." 15 The court held that such reliance without fully investigating the authenticity of the object could not be deemed to be reasonable given that "ACA [was] in the business of buying and selling art [and must therefore have been] cognizant of forgery of the works of well-known artists like Avery." 16 The court observed that, depending on the situation, diligence might mean seeking authentication through an artist's foundation, calling upon additional experts, requesting detailed documents, or consulting lawyers.

In another recent decision, the Swiss Supreme Court held that a collector had not employed all necessary due diligence when buying a Malevich painting. ${ }^{17}$ In that case, the collector had carried out a substantial amount of research before buying the painting in July 1989, including consulting an art expert in Russian avant-garde as to the authenticity and origin of the painting. Interpol and the Soviet Embassy were also contacted in connection with the purchase. It appears that the art expert warned the collector about a stolen painting of Malevich supposedly being on the market, albeit without identifying the relevant painting as the stolen work. The Swiss Supreme Court considered that the collector had not shown enough diligence in this case, and should have solicited the opinion of another expert in order to remove any doubt as to the origin of the work in light of the first expert's warning that there was a stolen Malevich painting on the market. Holding that the purchaser had acted in bad faith, the Swiss Supreme Court should arguably have granted the applicant's claim for recovery of property. However, the Court instead referred the case back to the lower court to determine whether the applicant had himself acquired the painting in good faith, on the basis that a purchaser in bad faith may refuse to return an object by establishing that the applicant had also acquired it in bad faith. This case importantly sets a more stringent threshold for the exercise of due diligence, requiring a buyer to obtain a second expert opinion and remove any doubt as to the origin of the object.

These cases illustrate a general trend towards a more stringent test to meet the due diligence threshold; actors of the art market may find it difficult to determine how far-reaching their enquiries must be in order to meet their due diligence obligations and for their purchases to be deemed to have been made in good faith.

\section{Due diligence: An ethical concept}

The concept of due diligence is further delineated in professional and ethical rules, as set forth in codes of conduct, codes of practice, or codes of ethics drafted by professionals in the art market.

By way of illustration, the ICOM Code of Ethics for Museums defines due diligence as follows in its glossary: "the requirement that every endeavour is made 
to establish the facts of a case before deciding a course of action, particularly in identifying the source and history of an item offered for acquisition or use before acquiring it." 18 Article 2.3 of this Code adds that:

every effort must be made before acquisition to ensure that any object or specimen offered for purchase, gift, loan, bequest, or exchange has not been illegally obtained in, or exported from its country of origin or any intermediate country in which it might have been owned legally (including the museum's own country). Due diligence in this regard should establish the full history of the item since discovery or production.

A number of other international codes of practice or ethics include due diligence obligations with varying degrees of detail such as the UNESCO International Code of Ethics for Dealers in Cultural Property, the Association of International Antiquities Dealers (AIAD) Code of Conduct, the Rules of the International Association of Dealers in Ancient Art (IADAA), the International Confederation of Art Dealers (Confédération Internationale des Négociants en Oeuvres d'Art, CINOA) Code of Ethics, or the International League of Antiquarian Booksellers (ILAB) Code of Ethics. These codes aim at developing a positive public image of - and maintaining public confidence in-both the art market in general and the professionals associated with it. ${ }^{19}$ Violations of these codes can lead to various sanctions such as warnings, disciplinary actions or dismissal from a professional body. These ethical and professional notions of due diligence may also help courts shape the contours of the legal meaning of due diligence and offer some guidance to lawyers advising parties in the context of art transactions.

\section{LAWYERS’ DUE DILIGENCE OBLIGATIONS}

This section will examine the due diligence obligations of lawyers with a special focus on art lawyers and will take a closer look at lawyers' professional secrecy and legal privilege, their duty to report, and their duty to terminate their mandate.

\section{The Lawyers' Duty of Diligence}

Sources of due diligence obligations binding upon lawyers include contract law, statutes regulating lawyers, and professional rules.

Lawyers' due diligence obligations arise primarily from their contractual relationships with clients. In civil law countries, provisions regarding the mandate (or agency agreement) govern the lawyer-client relationship, imposing on lawyers a comprehensive duty of loyalty towards the client, which includes the obligation to treat the client's affairs as privileged and confidential. ${ }^{20}$ To a large extent, it is the agreement between the lawyer and the client that will determine the scope of the due diligence which can be expected from a lawyer. The lawyer's own claims regarding his or her expertise and competence are also elements which are taken into account when assessing the scope of the duty of diligence. In general, a lawyer 
will focus on the legal background of the transaction, and the duty of diligence will be assessed in light of this purely legal analysis, excluding any art expertise.

Lawyers who are members of professional organizations also may have to abide by codes of ethics or professional rules, which may be used as guidance to shape the contours of their duty of diligence. ${ }^{21}$

An example of a due diligence obligation incumbent upon lawyers is the obligation set out by statute - in contrast to the contract - to identify risks of money laundering activities. Beyond the general duty to gather all the information necessary to provide a lawyer with a comprehensive view of the matter at stake, lawyers may be required in certain cases - to the extent possible-to verify independently the information provided to them. For instance, this would be the case where there are reasons to believe that the transaction envisaged may involve money laundering, as when a transaction involves the purchase of a high-value painting via a myriad of corporate entities registered in offshore jurisdictions, the issuance of a fake invoice executing a fictitious purchase, or fake auctions, where an accomplice buys an artwork with funds provided by the seller himself. ${ }^{22}$ The issue is often to determine how far the lawyer should investigate the background of the transaction.

In France for instance, the National Bar Council considers that a high standard of due diligence must be applied so that lawyers not only ask clients questions, but also gather information and evidence to support their clients' answers. ${ }^{23}$ Pursuant to the applicable professional and ethical rules, French lawyers have to identify precisely their clients and the parties involved and not only assess the situation described by their clients, but also the nature and scope of the legal transaction. ${ }^{24}$ The purpose of this "client due diligence" is notably to prevent lawyers from becoming accomplices to criminal offenses, such as money laundering, concealment or forgery. Another reason is to avoid lawyers being used to set up fraudulent schemes. Lawyers should be particularly diligent where the relevant transactions involve large sums of money or have a complex structure, or where the economic justification for the transaction has not been disclosed. ${ }^{25}$ In art-related matters, lawyers must pay particular attention to the origin and provenance of the artwork or cultural good, especially where the origin is not accurately documented.

Very generally, due diligence obligations applicable to lawyers can be narrowed down to due diligence obligations: (i) towards clients and (ii) towards the State. Due diligence obligations towards clients, including the duty to act in the client's interests or the duty of confidentiality, are essential to the relationship of trust that exists between lawyers and their clients. At the same time, it is important for the justice process that the trust placed in the legal professional is not abused and that lawyers respect the due diligence obligations imposed upon them by the State when faced with potentially illegal activities. As a result, lawyers can find themselves in a precarious situation, torn between their obligations towards their clients and towards the State's legal system.

This pressure is likely to be felt by art lawyers in particular because of the specificities of the art market which is generally unregulated, lacks transparency, and 
operates in grey areas often involving many offshore corporate structures, as well as a complex interaction between rules of several jurisdictions. The relative impenetrability of the art world, and the fact that it is often the scene of illegal activities, raises the question of whether art lawyers should act as "guardians" of the art market.

\section{The Role of Art Lawyers}

Alongside collectors, dealers, experts, and auctioneers, lawyers specialized in artrelated matters play an essential role in the art market. They advise clients on transactions, draft legal documents and, when disputes arise, represent parties before courts or arbitral tribunals.

The role played by lawyers allows them to be the privileged witnesses of the inner workings of the art world and to contemplate art transactions from a legal and objective standpoint, different to that of art lovers for whom emotions can sometimes trump rationality. Art transactions are often of a complex and international nature, involving numerous actors, interests and issues, relating inter alia to property law, contract law, tax law, trade law, administrative law, or conflict of laws. In this context, thorough and specialized legal advice from a lawyer with specific expertise in art law contributes to the success of art transactions and the avoidance of unintended legal consequences (e.g. restitution obligations or criminal sanctions).

As mentioned, in addition to the role they perform for their clients, lawyers also have a specific role to play in the judicial process. ${ }^{26}$ The relationship between attorney/lawyer and his or her client comes with privileges such as lawyer confidentiality and attorney-client privilege. Lawyers must beware of not grantingwilfully or negligently-the benefit of such privilege to assist in the concealment of fraudulent art transactions. Statutes and professional and ethical rules have been designed to protect public confidence in the legal profession and to ensure a proper administration of justice.

Apart from these rules, there are no specific guidelines as to how art lawyers should reconcile their role towards their client and within the justice process with the specificities of art-related matters.

The "right" thing to do could be difficult to identify when confronted with clients requiring advice and document drafting in the context of transaction involving antiquities allegedly inherited from a deceased ancestor having fled a country ravaged by war without anything except a beautiful artwork and obviously no paperwork, or who claim to have legally imported works of art from a country which imposes strict conditions and severe restrictions on art export, without evidence of import license and excuses which may or may not be valid. The same holds true for transactions which involve a complex web of offshore companies which prevent the good understanding of the background of the transactions and in particular of the identity of the true owner of the artwork, or transactions related to artworks which 
may contain material subject to sanction lists (e.g. ivory or Burmese sapphires) or whose origin (and hence authenticity) is highly questionable.

\section{Professional Secrecy and Legal Privilege}

In most-if not all-jurisdictions, lawyers have a duty to observe professional secrecy and are entitled to claim legal professional privilege, institutions of the utmost importance to their proper functioning as lawyers and for the trust placed in them by their clients. A violation of lawyers' secrecy duties may entail contractual liability, disciplinary action, or criminal sanctions. The professional secrecy of dealings with lawyers may be guaranteed by criminal law, as is the case in Switzerland, Italy, and France, ${ }^{27}$ and/or by statutory law regulating the legal profession, such as the German or Swiss Lawyers' Acts. ${ }^{28}$ In the United Kingdom, legal professional privilege and confidentiality are common law principles stated by courts as a fundamental feature of the administration of justice and the Rule of Law. ${ }^{29}$ Lawyers are also generally protected against the obligation to give evidence against clients in codes of criminal procedure, such as those applicable in Italy or in Switzerland. ${ }^{30}$

Professional secrecy is also reflected in different professional codes of conduct for lawyers, such as Section 2.3 of the Code of Conduct for Lawyers in European Union or in Rule 1.6 of the American Bar Association Model Rules of Professional Conduct (ABA Model Rules), according to which a lawyer is not allowed to reveal information relating to his or her representation of a client unless the client gives informed consent or tacitly authorises the lawyer to do so.

However, professional secrecy may usually be waived by the client, and certain rules may override the general duty of professional secrecy. Such rules can be found in regulations which aim at fighting illegal activities, especially money laundering. For example, in the United Kingdom, courts have held that legal professional privilege is not applicable where the communication by the lawyer is made for the purpose of advising a client regarding the commission of a crime, or if the lawyer is involved in executing the criminal or illegal act. ${ }^{31}$ Pursuant to Rule 1.6(b) of the New York Rules of Professional Conduct (NYRPC), lawyers are permitted to reveal confidential information to the extent necessary to prevent the client from committing a crime. In this respect, the NYRPC goes beyond the ABA Model Rules as the latter limits the scope of the disclosure right to that which is necessary to prevent a "crime likely to result in imminent death or substantial bodily harm" (ABA Model Rule 1.6(b)(1)). Professional secrecy is therefore a relative concept and art lawyers can find themselves in a position to denounce a client who is about to commit a crime. By doing so, they may act as "guardians" of the art market.

\section{“Hey! Wait a Minute.”: A Duty to Report?}

Lawyers' professional secrecy is not absolute and may be lifted, notably to combat money laundering and terrorist financing. Under certain circumstances, lawyers 
have a duty to report criminal activities involving their clients and may therefore play an important role in preventing criminal activities relating to art or cultural goods transactions.

\section{The FATF Recommendations}

Legal professionals have been included in the 2012 FATF Recommendations to combat money laundering and terrorist financing. ${ }^{32}$ Pursuant to Recommendations 22(d) and 23(a), legal professionals must, when they engage in certain financial activities described under Recommendation 22(d), undertake a thorough Customer Due Diligence (CDD) and complete a Suspicious Transaction Report (STR) if they suspect criminal activities.

It is noteworthy that the FATF has now expanded the scope of money laundering predicate offenses by including serious tax crimes. This will bring the proceeds of tax crimes within the scope of the powers used to investigate money laundering. The offense of smuggling has also been expanded to include offenses relating to customs and excise duties and taxes. ${ }^{33}$ This is likely to have important implications for the due diligence to be exercised in relation to international art transactions. Indeed, complex offshore structures, once favored for their tax-mitigation or even tax-avoidance impact, will have to be reassessed in light of the new standards set by the FATF, thus requiring an extra duty of care on the part of all the advisors involved, including art lawyers.

Building on its 2012 Recommendations, the FATF issued, in June 2013, a "Report on the Vulnerabilities of Legal Professionals in the Context of Money Laundering and Terrorist Financing" which seeks to determine the degree to which legal professionals in general are likely to be involved in money laundering. ${ }^{34}$ The report identifies a range of services provided by legal professionals that are attractive to criminals wanting to launder the proceeds of their criminal activity. Some of the services identified include the use of trust accounts held for clients, the purchase of real property, the creation of trusts and companies, the management of trusts and companies, the setting up and the management of charities and the purchasing of real estate. The report does not specifically mention art transactions. However, the FATF already acknowledged in its 1997-1998 Report on Money Laundering Typologies that "sellers of high-value objects like artworks are unquestionably a significant presence in laundering activities." 35

The 2013 report on legal activities concludes that criminals seek out the involvement of legal professionals in their money laundering or terrorist financing activities, sometimes because a legal professional is required to complete certain transactions, sometimes to access specialized legal and notarial skills and services that assist the laundering of the proceeds of crime or the funding of terrorism, and other times simply because the involvement of legal professionals adds perceived respectability to a transaction.

As illustrated by the Security Council Resolution 2199 of 12 February 2015, the trade in cultural goods can also be connected with terrorism financing as is the case 
with IS which is funding its horrendous activities through trafficking of Iraqi and Syrian cultural goods. ${ }^{36}$ This trafficking has led the Security Council to condemn the destruction of cultural heritage in Iraq and Syria and to call on the Member States to take necessary measures to prevent the trade in cultural property illegally removed from Iraq since August 1990 and from Syria since March 2011. ${ }^{37}$ The FATF Recommendations aiming to combat money laundering and terrorist financing are therefore directly relevant to the art market—and to art lawyers.

\section{European and Domestic Law}

Many jurisdictions have incorporated the FATF Recommendations into their national anti-money laundering legislation, or have created new pieces of legislation specifically to incorporate the Recommendations.

In response to the FATF Recommendations applicable to the legal profession and considering that money laundering increasingly involves non-financial professions, the European Union has extended the scope of anti-money laundering obligations to lawyers. ${ }^{38}$ The third European Union Anti-Money Laundering Directive provides that lawyers have to report their suspicions of money laundering activities to the relevant national authorities without disclosing to their clients that such a step was undertaken. ${ }^{39}$

The duty to report suspicious activities under the third Money Laundering Directive does not concern all of a lawyer's activities. In particular, Article 23(2) of the Directive states that it does not apply:

with regard to information lawyers receive from or obtain on one of their clients, in the course of ascertaining the legal position for their client or performing their task of defending or representing that client in, or concerning judicial proceedings, including advice on instituting or avoiding proceedings, whether such information is received or obtained before, during or after such proceedings.

In France, a national authority named TRACFIN (Traitement du Renseignement et Action Contre les Circuits Financiers Clandestins) was created in 2006, and the French Monetary and Financial Code was amended to provide an obligation for lawyers to prepare suspicion reports where they suspect or have good reasons to suspect that money laundering is involved in transactions. Such reports must include the reported client's occupation, identity and professional details, along with the beneficial owner of the object at the heart of the transaction. They must also include a description of the relevant transaction, its main steps, and the reasons justifying the decision to report it. Suspicion reports are in principle confidential. As compared to the stricter terms of the European Union's Third Anti-Money Laundering Directive, French lawyers need not submit their suspicion reports directly to TRACFIN, but may first submit it to the president of the Bar to which they belong. This derogation is based on the principle of lawyers' professional secrecy provided by French law as well as professional and ethical rules and standards. The European Court of Human Rights (ECHR) upheld this approach, holding that, as 
far as professional secrecy is concerned, it is appropriate for a lawyer to submit his or her suspicion report to the president of his or her Bar, who, also being a lawyer elected by his or her peers, is subject to professional secrecy. ${ }^{40}$ Neither the reporting lawyer, nor the president of the Bar may inform the client that its transaction has been reported to TRACFIN.

German law adopts a similar approach to that taken by French law. Pursuant to the German Money Laundering Act, lawyers again have an obligation to report any suspicious activity where they know, suspect, or have reasonable grounds to suspect that money laundering or terrorist financing is being or has been either committed or attempted. ${ }^{41}$ However, Article 12 of the German Money Laundering Act specifies that said obligation to report does not apply to professionals (including lawyers):

for the information that they have acquired from their client or regarding their client, when ascertaining the legal position of the client or representing or defending the client in legal proceedings or in connection with such proceedings, including when providing advice on instituting or avoiding legal proceedings, when such information is received or obtained before, during or after the same proceedings.

In the same vein, Swiss law distinguishes between the typical activities of giving legal advice and representing clients before courts and atypical activities of lawyers such as acting as financial intermediaries for clients or acting as the client's business partner. While there is no duty to report for lawyers practising a typical activity, lawyers acting as financial intermediaries are subject to the Federal Act on Combatting Money Laundering. Accordingly, in cases where a lawyer acting as a financial intermediary knows or has a reasonable suspicion that the assets involved in the business transaction are linked to money laundering or the financing of terrorism, he must report the same without delay to the Money Laundering Report Office Switzerland (MROS). ${ }^{42}$ A lawyer coming across a transaction involving Mesopotamian antiquities presumably originating from Syria or from Iraq without accurate information as to their origin may be confronted with the difficult question on whether to report the transaction and its actors to the relevant authorities.

In the United States, under ABA Model Rules 1.6 and 3.3, if a lawyer takes cognisance of a misrepresented material issue by a client in a civil case's deposition, the lawyer has to advise the client to correct the testimony. In the event that the client refuses to do so, the lawyer must disclose the false statement to the court, all the while minimizing the disclosure of confidential information. The lawyer is also required to withdraw any false evidence, even if such disclosure to a court would reveal confidential information. However, the attorney should use other, less harmful, measures to the extent that they are available to rectify the falsehood. ${ }^{43}$

\section{“Thanks, but No.": A Duty to Terminate a Mandate?}

Another important aspect of lawyers' due diligence when involved in suspicious transactions is the duty to withdraw from representation or to terminate their mandate. 
In the United States, under the ABA Model Rules, a lawyer may not assist a client in conduct that he or she knows is criminal or fraudulent. A lawyer who believes that legal services are being used in the furtherance of a crime or fraud has the obligation to cease representing the client. A lawyer may also disclose a client's wrongdoing if the legal services were used in perpetuating the crime or fraud and if the lawyer believes that such disclosure is necessary to prevent the client from committing the crime. A lawyer may also be required to withdraw from representing a client pursuant to the rule prohibiting a lawyer from assisting a client in criminal or fraudulent conduct. ${ }^{44}$

Interestingly, such a rule is generally absent from other professional codes or rules regulating the lawyers' profession. Yet, such a duty is implicit in, and is a natural consequence of, the general duty of each individual not to commit or be accomplice to criminal offenses (e.g. prohibition of handling stolen goods). Given the confidentiality obligation imposed upon lawyers regarding their activities, the only ethical and "right" thing to do when in doubt as to the legality or ethical nature of a transaction is to carefully consider whether or not to terminate the mandate. This option is all the more important for art lawyers to ponder given the exceptional circumstances of the cases they are often asked to handle.

\section{A NEED FOR MORE REGULATION?}

Against this background, namely the particularities of the art market as well as the privileged role that lawyers play, the questions can be raised of whether lawyers should be the "guardians" of the art market and whether there is a need for more regulation in relation to art lawyers' due diligence obligations.

A first attempt to address this question was made at the "All Art and Cultural Heritage Law Conference” held by the Art-Law Centre of the University of Geneva which particularly touched upon the issue of developing due diligence, expert interaction, and quality impulse in the art market. ${ }^{45}$ To support the discussion, an electronic survey was launched prior to the conference and sent to a selection of art law specialists.

Interestingly, as to the question of whether regulations or professional/ethical guidelines on due diligence obligations were needed for lawyers operating in the art market, about 53\% strongly agreed or agreed, and 37\% strongly disagreed or disagreed. Of the former group, $80 \%$ considered that the appropriate form for such rules would be international professional guidelines, with $50 \%$ supporting the use of national professional guidelines and only $20 \%$ considering regulations to be the best solution.

This data, while rich in lessons, should only be considered as a preliminary indication of a trend on account of the limited number of persons that were surveyed. The data nonetheless evidences a desire on the part of art law specialist for guidance, if not more regulation.

Given the international trend towards increased transparency and accountability in particular in important financial sectors, the art law community should reflect upon the best ways to ensure that standards of due diligence are put in place and 
adequately balance the interests of clients against those of the larger community in the fight against crimes and the administration of justice.

\section{CONCLUSION}

Outlining the scope of lawyers' due diligence obligations in the art market is a complex task. The general concept of due diligence depends on many factors, including the professional qualifications and specific knowledge of individual actors. Applied to the specific situation of lawyers, the task can become even more complex given the inherent tension between the duty of diligence owed by lawyers to their clients and that owed to the community to ensure the administration of justice. This tension may be particularly acute for art lawyers, given the high financial stakes at play in the art market and the number of illegal activities taking place in this rather confidential, privy, if not opaque environment. Lawyers are not art specialists. They may however have serious suspicions as to the legality of a transaction involving complex offshore structures without specific reasons or antiquities from countries at war without traceable origin. In such situations, the dilemma may arise on whether to report the transaction or whether to withdraw from the transaction, the latter being advisable in case of doubt. Guidelines or best practices for art lawyers could be a tool to enable them to better deal with unusual transactions.

In this period of increasing regulatory initiatives at the international level in all fields where the financial stakes are high, it seems important for legal professionals active in the art world to carefully consider the scope of their due diligence obligations in order to ensure a sustainable practice and to avoid the unfortunate consequences and sanctions that have befallen other sectors, such as the financial and banking sectors, as a result of ongoing abuses in such sectors. One can remain hopeful that this will be achieved in light of the creativity of the art world and the interest involved actors have in a stable and a thriving art market.

\section{ENDNOTES}

1. See Alexander Forbes, "What You Need to Know about Master Forger Wolfgang Beltracchi's Latest Antics," Artnet News, 3 March 2014, http://news.artnet.com/market/what-you-need-to-knowabout-master-forger-wolfgang-beltracchis-latest-antics-3292 (accessed 19 August 2015); Mary Emily O'Hara, "Master Painter Accused of Forging Rothko, Pollock, and Others in \$33 Million Art Scam," Vice News, 22 April 2014, https://news.vice.com/article/master-painter-accused-of-forging-rothko-pollockand-others-in-33-million-art-scam (accessed 19 August 2015) in regards to Pei-Shen Qian; Roger Atwood, “Inside Iraq's National Museum,” Artnet News, 1 July 2003, www.artnews.com/2003/07/01/ inside-iraqs-national-museum (accessed 13 July 2015); Sarah Cascone, "Syria's Cultural Artifacts Are Blood Diamonds for ISIS,” Artnet News, 9 September 2014, http://news.artnet.com/art-world/syriascultural-artifacts-are-blood-diamonds-for-isis-96814 (accessed 19 August 2015).

2. UNESCO 2011.

3. Ibid. 
4. See Dietzler 2013.

5. Mark V. Vlasic, "Islamic State sells 'blood antiquities' from Iraq and Syria to raise money," Washington Post, 14 September 2014, www.washingtonpost.com/opinions/islamic-state-sells-bloodantiquities-from-iraq-and-syria-to-raise-money/2014/09/14/49663c98-3a7e-11e4-9c9f-ebb47272e40e_ story.html?tid=HP_opinion (accessed 13 July 2015); see also Sangwon Yoon, "Islamic State is Selling Looted Art Online for Needed Cash,” Bloomberg News, 28 June 2015, www.bloomberg.com/news/ articles/2015-06-28/isis-has-new-cash-cow-art-loot-it-s-peddling-on-ebay-facebook (accessed 13 July 2015).

6. European Commission Directorate-General Home Affairs 2011.

7. Article 16, Swiss Cultural Property Transfer Act 2003 (loi fédérale sur le transfert international des biens culturels).

8. Section 5, UK Money Laundering Regulations 2007.

9. Article 87a, Dutch Implementation Act for the 1970 UNESCO Convention.

10. For instance in France, Germany, Austria, and Switzerland; cf. Renold 2013.

11. Winkworth v. Christie, Manson \& Wood Ltd., [1980] 1 Ch. P. 496, [1980] 1 All E.R. p. 1121 [1980] 2 W.L.R. p. 7, Nov. 51979.

12. Renold 2013.

13. FATF 2012, Recommendation 3 and General Glossary: definition of "designated categories of offenses."

14. ACA Galleries, Inc. v Kinney, 2013 WL 638835 S:D:N:Y: 2013.

15. Ibid., 3.

16. Ibid., 4.

17. Decision of the Swiss Supreme Court ATF 139 III 305.

18. See The ICOM International Observatory on Illicit Traffic in Cultural Goods, "Due Diligence / Good Faith,” http://obs-traffic.museum/due-diligence-good-faith (accessed 19 August 2015).

19. Bellingham 2008.

20. In Germany: Section 675 of the German Civil Code (Bürgerliches Gesetzbuch); in Italy: Articles 1176 ss. of the Civil Code (Codice Civile); in France: Articles 1991 ss. of the Civil Code (Code civil); in Switzerland: Article 398 ss. of the Code of Obligations (Code des obligations).

21. For example: CCBE Code of Conduct of Lawyers in the European Union, www.ccbe.eu/fileadmin/ user_upload/NTCdocument/EN_CCBE_CoCpdf1_1382973057.pdf (accessed 13 July 2015); Rules on professional conduct for lawyers; Swiss Lawyer Association, www.oav.ch/docs/code-suissede-deontologie.pdf (accessed 13 July 2015); or ABA Model Rules of Professional Conduct.

22. Rapport sur l'évaluation nationale des risques de blanchiment d'argent et de financement du terrorisme en Suisse, Groupe interdépartemental de coordination sur la lutte contre le blanchiment d'argent et le financement du terrorisme (GCBF), June 2015, 118, www.news.admin.ch/NSBSubscriber/ message/attachments/39966.pdf (accessed 13 July 2015).

23. National Bar Council Guide, Dissuader pour ne pas dénoncer, January 2012, 28 ss, http://cnb. avocat.fr/file/121398/ (accessed 13 July 2015). This guide was published by The French National Bar Council to help lawyers implementing their duty of care and duty to report suspicion.

24. Article 1(5) of the National Legal Ethics Code and the Internal Rules of the Paris Bar (Règlement intérieur du Barreau de Paris).

25. National Bar Council Guide 2012.

26. In Switzerland, lawyers are even considered as "auxiliaires de justice"; see in particular Decision of the Swiss Supreme Court ATF 106Ia 100. The particular role of lawyers in the justice process has also been raised by the European Court of Justice in ECHR, 20 May 1998, No 56/1997/840/1046, Schöpfer v Suisse.

27. Article 261 of the Swiss Criminal Code; Article 226-13 of the French Criminal Code; Article 622 of the Italian Criminal Code.

28. In Germany: Section 43a(2) of the Federal Lawyers' Act (Bundesrechtsanwaltordnung); in Switzerland: Article 13 of the Swiss Lawyers' Act (Loi sur la libre circulation des avocats).

29. For example: R. v. Secretary of State for Home Department, Ex p. Daly [2001] 3 AER 433. 
30. Article 200 of the Italian Code of Criminal Procedure; Article 171 of the Swiss Code of Criminal Procedure.

31. For example, Micosta SA v. Shetland Islands Council 1983 SLT 483.

32. FATF 2012.

33. See ibid., Recommendation 3 and General Glossary, definition of "designated categories of offenses"; see also "FATF Steps Up the Fight against Money Laundering and Terrorist Financing," FATF Recommendations, 16 February 2012, http://www.fatf-gafi.org/topics/fatfrecommendations/ documents/fatfstepsupthefightagainstmoneylaunderingandterroristfinancing.html (accessed 13 July 2015).

34. See FATF 2013.

35. See FATF 1998, Annex C: Report on Money Laundering Typologies, 55, para. 62.

36. Bauer 2015.

37. Resolution 2199. 2015. Adopted by the Security Council at its 73rd meeting, on 12 February 2015, Section 17.

38. European Directive No. 2001/97/EC, 4 December 2001, Recitals 16 and 17.

39. Articles 2(3)(b) and 28(1) of the European Directive No. 2005/60/EC, 26 October 2005, on the Prevention of the Use of the Financial System for the Purpose of Money Laundering and Terrorist Financing.

40. ECHR, 6 December 2012, No 12323/11, Michaud v. France.

41. Article 41 of the German Money Laundering Act (Geldwäschegesetz).

42. Articles 2 and 9 of the Federal Act on Combating Money Laundering (Loi fédérale concernant la lutte contre le blanchiment d'argent et le financement du terrorisme dans le secteur financier).

43. New York Rules of Professional Conduct, Rule 3.3.

44. ABA Model Rules 1.2(d) and 1.16.

45. 1st "All Art and Cultural Heritage Law Conference," Art-Law Centre, University of Geneva, 14 June 2015, www.art-law.org/centre/all-art/programme_colloque_artLaw13-14_juin.pdf (accessed 13 July 2015).

\section{BIBLIOGRAPHY}

Bauer, Alexander A. 2015. "Editorial: The Destruction of Heritage in Syria and Iraq and Its Implications." International Journal of Cultural Property 22, no. 1: 1-6.

Bellingham, David. 2008. "Ethics and the art market." In The Art Business, edited by Iain Robertson and Derrick Chong, 176-195. New York-London: Routledge.

2014. "The Underwater Heritage of the Riace Bronzes: Ethics, Provenance and the Art in Ancient Rome and Today." In Art Cultural Heritage and the Market: Ethical and Legal Issues, edited by Valentina Vadi and Hildegard E. G. S. Schneider, 141-164. Berlin Heidelberg: Springer-Verlag.

Chappuis, Benoît. 2013. "Le secret de l'avocat face aux exigences de la lutte contre le blanchiment d'argent: l'avis de la Cour européenne des droits de l'homme." Forumpoenale 6, no. 2: 118-24.

Dietzler, Jessica. 2013. "On Organized Crime in the Illicit Antiquities Trade: Moving Beyond the Definitional Debate.” Trends in Organized Crime 16, no. 3: 329-42.

Financial Action Task Force (FAFT). 1998. “Annual Report, 1997-1998.” Paris: FATF, www.fatf-gafi. org/media/fatf/documents/reports/1997\%201998\%20ENG.pdf (accessed 8 July 2015).

2012. "International Standards on Combating Money Laundering and the Financing of Terrorism \& Proliferation — the FATF Recommendations." Paris: FATF, http://www.fatf-gafi.org/media/ fatf/documents/recommendations/pdfs/FATF_Recommendations.pdf (accessed 10 July 2015). 
2013. "FATF Report: Money Laundering and Terrorist Financing Vulnerabilities of Legal Professionals." Paris: FATF, http://www.fatf-gafi.org/media/fatf/documents/reports/ML\%20and\%20 TF\%20vulnerabilities\%20legal\%20professionals.pdf (accessed 10 July 2015).

Graham, Jason-Louise. 2014. "Art Exchange? How the International Art Market Lacks a Clear Regulatory Framework." In Art Cultural Heritage and the Market: Ethical and Legal Issues, edited by Valentina Vadi and Hildegard E. G. S. Schneider, 319-40. Berlin Heidelberg: Springer-Verlag.

Prowda, Judith B. 2014. "The Perils of Buying and Selling Art at the Fair: Legal Issues in Title." In Art Cultural Heritage and the Market: Ethical and Legal Issues, edited by Valentina Vadi and Hildegard E. G. S. Schneider, 141-63. Berlin Heidelberg: Springer-Verlag.

Renold, Marc-André. 2013. “Stolen Art: The Ubiquitous Question of Good Faith.” In Resolution of Cultural Property Disputes, edited by The International Bureau of the Permanent Court of Arbitration, 251-63. The Hague: Kluwer Law International.

Merryman, John H., Albert E. Elsen, and Stephen K. Urice. 2007. Law, Ethics and the Visual Arts. 5th ed. Alphen aan den Rijn: Kluwer Law International.

UNESCO. 2011. "The Fight against the Illicit Trafficking of Cultural Objects: The 1970 Convention: Past and Future." Information Kit. Division of Public Information and the Culture Sector of UNESCO, Paris, http://unesdoc.unesco.org/images/0019/001916/191606e.pdf (accessed 10 July 2015).

Von Fliedner, Isabel. 2010. "Le secret professionnel de l'avocat et le blanchiment: notes de droit comparé." Revue de l'avocat 13, no. 1: 49-54. 